\title{
In-Vitro Development and Characterisation of a Superoxide Dismutase-Based Biosensor.
}

\author{
Michelle M. Doran,* Niall J. Finnerty, and John P. Lowry* ${ }^{*[a]}$
}

\begin{abstract}
A first generation amperometric biosensor for the detection of superoxide $\left(\mathrm{O}_{2}^{-}\right)$was constructed utilising a dip-coating approach for immobilising the enzyme superoxide dismutase (SOD, $200 \mathrm{U} / \mathrm{mL}$ ) onto a Pt electrode. Several dip-coating procedures were investigated, incorporating styrene, glutaraldehyde, bovine serum albumin and polyethylenimine at various concentrations, in order to develop a simple and reproducible coating method to maximise the sensitivity of the sensor to $\mathrm{O}_{2}^{-}$. The optimised design was produced using 5 dip-coatings and a composite containing $200 \mathrm{U} / \mathrm{mL}$ SOD, $0.5 \%$ glutaralde-
\end{abstract}

\section{Introduction}

The biological reactive oxygen species (ROS) superoxide $\left(\mathrm{O}_{2}^{-}\right)$is generated as a reduced intermediate of molecular oxygen $\left(\mathrm{O}_{2}\right){ }^{[1,2]}$ Its major source in cells is electron 'leakage' from electron transport chains in the mitochondria and in the endoplasmic reticulum..$^{[3]}$ Under normal metabolic conditions ROS are produced at a rate which is matched by the capacity of tissues to catabolise them. ${ }^{[4,5]}$ However, when their production exceeds the body's natural ability to deal with this potentially cytotoxic process, a variety of pathological conditions may occur, including stroke, cancer and neurodegeneration. ${ }^{[6,7]}$ This is true for $\mathrm{O}_{2}^{-}$which under normal physiological conditions has a very low nanomolar concentration $(10-100 \mathrm{nM})^{[8]}$ due to the natural ability of superoxide dismutase (SOD) to catalyse its dismutation and its high reactivity with other small molecules. ${ }^{[9,10]}$

Several techniques for measuring the concentration of $\mathrm{O}_{2}$ indirectly are currently available including electron spin resonance (ESR), ${ }^{[11-13]}$ chemiluminescence ${ }^{[14-17]}$ or certain semiquantitative colorimetric tests. However, none of these are suitable for direct monitoring in biological tissues and recently electrochemical techniques have become popular in order for direct real-time monitoring of $\mathrm{O}_{2}^{-}$. Several first, ${ }^{[18,19]}$ second ${ }^{[20,21]}$ and third generation ${ }^{[22-26]} \mathrm{O}_{2}^{-}$biosensors have been developed for $\mathrm{O}_{2}^{-}$monitoring. These sensors have utilised various transducers including $\mathrm{Pt}, \mathrm{Au}$ and carbon fibre and various immobilisation

[a] Dr. M. M. Doran, Dr. N. J. Finnerty, Prof. J. P. Lowry

Neurochemistry Laboratory, Maynooth University Department of Chemistry, Maynooth University, Maynooth, Co. Kildare, Ireland

E-mail: Michelle.Doran@nuim.ie

John.Lowry@nuim.ie

Supporting information for this article is available on the WWW under https://doi.org/10.1002/slct.201700793 hyde and $2 \%$ polyethylenimine (Sty-(SOD-0.5\%GA-2\%PEI) 5 ). This sensor displayed excellent permselective characteristics with negligible signals produced by 12 of the most common electroactive species present in brain extracellular fluid, including uric acid (UA) which is produced as a by-product of the $\mathrm{O}_{2}^{-}$ generating xanthine-xanthine oxidase calibration method. In addition, it had a response time of $c a .1 \mathrm{~s}$, high sensitivity to $\mathrm{O}_{2}^{-}(0.91 \pm 0.02 \mathrm{nA} / \mu \mathrm{M})$, and an in-vitro limit of detection of $c a$. $0.063 \mu \mathrm{M}$, thus suggesting potential use for neurochemical monitoring of $\mathrm{O}_{2}^{-}$in-vivo.

techniques. The most common methods of immobilisation include entrapment within a membrane, cross-linking, covalent bonding and physical adsorption. ${ }^{[27-29]}$ Few reports exist for measuring $\mathrm{O}_{2}^{-}$levels in-vivo in freely-moving animals because of its low concentration, fleeting existence and high reactivity in the in-vivo environment. For a number of years, in-vivo electrochemistry has been used for the detection of substances in the living brain. ${ }^{[30,31]}$ Our goal here is to utilise previous experience to develop a SOD-based biosensor for real-time neurochemical monitoring of $\mathrm{O}_{2}^{-}$in-vivo.

In this paper, we report the development of a first generation biosensor immobilising the enzyme SOD on a $\mathrm{Pt}$ electrode. In order to generate $\mathrm{O}_{2}{ }^{-}$in the electrochemical cell this biosensor utilises the classical xanthine-xanthine oxidase (XOD) reaction. ${ }^{[32]}$ XOD catalyses the univalent and divalent reduction of molecular $\mathrm{O}_{2}$ generating $\mathrm{O}_{2}{ }^{-}$and hydrogen peroxide $\left(\mathrm{H}_{2} \mathrm{O}_{2}\right)^{[33]}$ resulting in the oxidation of xanthine to uric acid (UA) as shown below;

Xanthine $+\mathrm{H}_{2} \mathrm{O}+\mathrm{O}_{2} \stackrel{x O D}{\longrightarrow} \mathrm{UA}+\mathrm{O}_{2}^{-}+2 \mathrm{H}^{+}$

The SOD immobilised on the electrode surface then catalyses the dismutation reaction of the $\mathrm{O}_{2}{ }^{-}$radical with the production of $\mathrm{O}_{2}$ and $\mathrm{H}_{2} \mathrm{O}_{2}$;

$2 \mathrm{H}^{+}+2 \mathrm{O}_{2}^{-\stackrel{S O D}{\longrightarrow}} \mathrm{H}_{2} \mathrm{O}_{2}+\mathrm{O}_{2}$

The $\mathrm{H}_{2} \mathrm{O}_{2}$ generated from this enzymatic process is oxidised at the electrode surface producing the signal generating current;

$$
\mathrm{H}_{2} \mathrm{O}_{2} \rightarrow 2 \mathrm{H}^{+}+\mathrm{O}_{2}+2 \mathrm{e}^{-}
$$

We initially utilised a dip-coating approach to create a composite layer of enzyme and stabilising agents in order to 
(a)

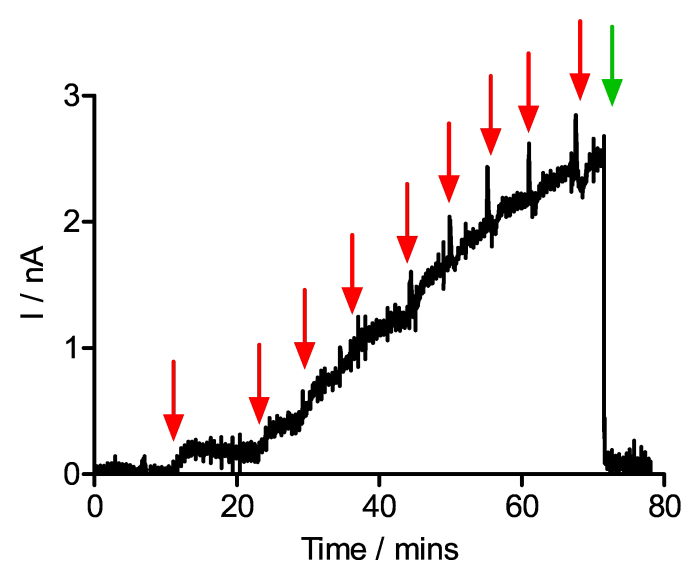

(b)

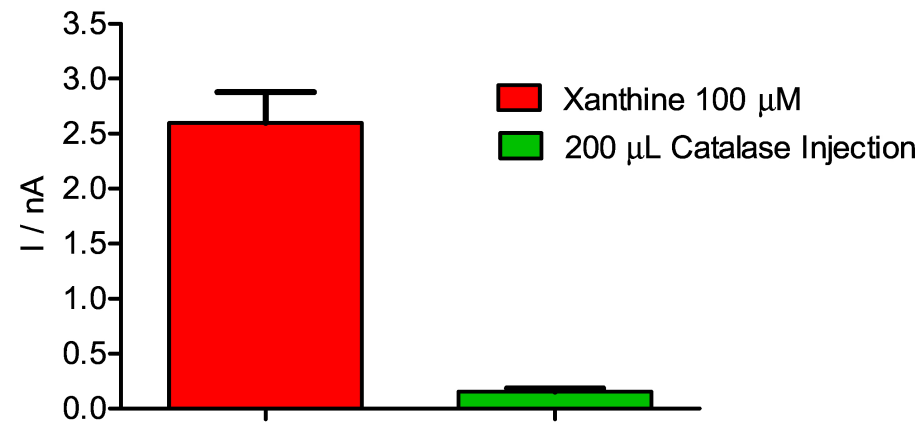

Figure 1. (a) Typical raw data trace for a xanthine-XOD calibration on a Pt-PPD sensor. The red arrows indicate sequential 1, 3, $6,10,20,40,60,80$ and $100 \mu M$ xanthine injections. The green arrow indicates a $200 \mu \mathrm{L}$ injection of catalase. Calibration performed using CPA at $+700 \mathrm{mV} v \mathrm{~s}$. SCE. (b) Bar chart showing the current comparison between $\mathrm{I}_{100 \mu \mathrm{m}}$ xanthine $(2.597 \pm 0.28 \mathrm{nA}, \mathrm{n}=6)$ prior to a $200 \mu \mathrm{L}$ injection of catalase on Pt-PPD sensors. The introduction of catalase resulted in an instantaneous decrease in current to baseline $(0.154 \pm 0.028 \mathrm{nA}, \mathrm{n}=6)$.

maximise sensitivity. This is critical in order to enable physiological monitoring of $\mathrm{O}_{2}^{-}$due to its nanomolar concentrations. In addition, we incorporated a permselective layer of poly-ophenylenediamine (PPD) which facilitated high permeability to the enzyme generated $\mathrm{H}_{2} \mathrm{O}_{2}{ }^{[34,35]}$ and effective rejection of the UA produced by the oxidation of xanthine in the in-vitro calibration process. This layer also eliminated signals from several endogenous interferent species including ascorbic acid (AA). ${ }^{[36,37]}$ The resultant fast responding, highly selective and sensitive biosensor has the potential for use in neurochemical monitoring of $\mathrm{O}_{2}^{-}$in-vivo.

\section{Results and Discussion}

\section{Interferents in Superoxide Calibration}

The $\mathrm{O}_{2}^{-}$radical is generated by the oxidation of xanthine to UA in the presence of XOD. However, UA is electroactive at the applied potential of $+700 \mathrm{mV}$ and therefore, its contribution to the biosensor's signal must be minimised. The inclusion of the permselective PPD layer prior to modification with the immobilising/stabilising components resulted in a significant decrease ( $P<0.0001)$ in the current recorded on addition of $100 \mu \mathrm{M}$ xanthine: $41.13 \pm 3.22 \mathrm{nA}$ (Bare $\mathrm{Pt}, \mathrm{n}=30$ ) to $2.02 \pm$ $0.17 \mathrm{nA}$ (Pt-PPD, $\mathrm{n}=16$ ). This result confirms that the UA current was effectively eliminated by incorporation of the PPD layer.

Additionally, the spontaneous dismutation of $\mathrm{O}_{2}^{-}$to $\mathrm{H}_{2} \mathrm{O}_{2}$ in the presence of excess $\mathrm{H}^{+}$ions is another potential source of interference which was verified by injecting a single $200 \mu \mathrm{L}$ aliquot of catalase into the electrochemical cell after the addition of $100 \mu \mathrm{M}$ xanthine. This produced an instantaneous decrease in current to baseline levels (see Figure 1(a) and (b)) suggesting that the spontaneous dismutation of $\mathrm{O}_{2}^{-}$is taking place in the electrochemical cell.
$\mathrm{O}_{2}^{-}$dismutation by SOD is first order with respect to $\mathrm{O}_{2}^{-}$ concentration whereas the spontaneous dismutation is second order, with a $\mathrm{pH}$ dependent second order rate of $\sim 10^{5} \mathrm{M}^{-1} \mathrm{~s}^{-1}$ at $\mathrm{pH}$ 7.0. ${ }^{[38]}$ The enzyme used in the development of this biosensor $\mathrm{Cu}, \mathrm{Zn}$ SOD accelerates the destruction of $\mathrm{O}_{2}$ increasing the rate constant of the dismutation reaction to $2 \mathrm{x}$ $10^{9} \mathrm{M}^{-1} \mathrm{~S}^{-1} \cdot{ }^{[39]}$ This suggests that SOD is more efficient at accelerating the decomposition of $\mathrm{O}_{2}^{-}$compared with the spontaneous dismutation, at low concentrations, therefore suggesting that the enzymatic dismutation of $\mathrm{O}_{2}^{-}$is more favourable than the spontaneous dismutation of $\mathrm{O}_{2}^{-}$in the electrolyte.

However, despite the need to eliminate the spontaneous dismutation few reports exist which distinguish this $\mathrm{H}_{2} \mathrm{O}_{2}$ from that generated by the enzymatic SOD reaction. Few research groups have manufactured first generation biosensors for the detection of SOD generated $\mathrm{H}_{2} \mathrm{O}_{2}$ which employ specific techniques to differentiate this $\mathrm{H}_{2} \mathrm{O}_{2}$ from the $\mathrm{H}_{2} \mathrm{O}_{2}$ produced by spontaneous dismutation. McNeil and co-workers developed a $\mathrm{O}_{2}^{-}$biosensor based on SOD-coated platinised carbon electrodes (PACE). The SOD-coated biosensor was polarised at $+320 \mathrm{mV}$ vs. $\mathrm{Ag} / \mathrm{AgCl}$ to estimate the $\mathrm{H}_{2} \mathrm{O}_{2}$ produced by the enzyme disproportionation of $\mathrm{O}_{2}^{-}$through its oxidation current. Similarly, this biosensor uses a subtraction method to eliminate the current generated due to the natural disproportionation of $\mathrm{O}_{2}^{-}$measured using a second electrode which consisted of bovine serum albumin (BSA) coated PACE. ${ }^{[40]}$

\section{Effect of Enzyme Concentration}

Synthetic polymers such as styrene and methyl methacrylate have been successfully used as enzyme immobilisers in the manufacture of biosensors for neurochemical monitoring. Both are liquids at room temperature and thus provide a convenient method for the entrapment of SOD using the dip-coating 


\begin{tabular}{|c|c|c|c|c|c|}
\hline Design & Composition & $\mathbf{n}$ & $\mathrm{V}_{\max } \mathrm{nA}$ & $\mathrm{K}_{\mathrm{m}} \mu \mathrm{M}$ & LRS $n A / \mu M$ \\
\hline 1 & Sty-(SOD(200U)) $)_{1}$ & 4 & $2.43 \pm 0.13$ & $7.57 \pm 1.51$ & $0.13 \pm 0.004$ \\
\hline 2 & Sty-(SOD $(200 U))_{2}$ & 4 & $8.56 \pm 0.12$ & $9.08 \pm 0.42$ & $0.41 \pm 0.02$ \\
\hline 3 & Sty- $(\operatorname{SOD}(200 U))_{5}$ & 8 & $5.65 \pm 0.24$ & $15.47 \pm 0.54$ & $0.52 \pm 0.02$ \\
\hline 4 & Sty- $(S O D(200 U))_{10}$ & 4 & $4.77 \pm 0.07$ & $5.08 \pm 0.30$ & $0.30 \pm 0.03$ \\
\hline 5 & Sty-(SOD $(100 U)_{5}$ & 12 & $7.40 \pm 0.10$ & $6.86 \pm 0.31$ & $0.41 \pm 0.03$ \\
\hline 6 & Sty- $\left(\mathrm{SOD}(400 U)_{5}\right.$ & 12 & $7.53 \pm 0.13$ & $8.28 \pm 0.46$ & $0.35 \pm 0.03$ \\
\hline 7 & Sty-(SOD-0.5\%GA) & 8 & $5.42 \pm 0.06$ & $6.87 \pm 0.25$ & $0.42 \pm 0.01$ \\
\hline 8 & Sty-(SOD-1 \%BSA-0.5\%GA) & 6 & $10.33 \pm 0.5$ & $15.02 \pm 1.46$ & $0.34 \pm 0.02$ \\
\hline 9 & Sty-(SOD-0.5\%GA-2\%PEI) & 17 & $15.98 \pm 0.15$ & $10.33 \pm 0.27$ & $0.91 \pm 0.02$ \\
\hline 10 & Sty-(SOD-0.5\%GA-1 \%PEI) & 12 & $10.05 \pm 0.10$ & $6.09 \pm 0.22$ & $0.85 \pm 0.04$ \\
\hline 11 & Sty-(SOD-0.5\%GA-3\%PEI) & 11 & $72.76 \pm 6.25$ & $100.30 \pm 15.26$ & $0.63 \pm 0.03$ \\
\hline 12 & Sty-(SOD-0.05\%GA-2\%PEI) & 8 & $60.08 \pm 5.56$ & $104.70 \pm 20.34$ & $0.63 . \pm 0.01$ \\
\hline 13 & Sty-(SOD-1 \%GA-2 \%PEI) $)_{5}$ & 7 & $40.38 \pm 1.90$ & $45.90 \pm 4.50$ & $0.51 \pm 0.01$ \\
\hline 14 & Sty-(SOD-1 \%BSA-0.5\%GA-2\%PEI) & 12 & $12.82 \pm 0.14$ & $21.82 \pm 0.53$ & $0.28 \pm 0.01$ \\
\hline 15 & Sty-(SOD-0.1\%BSA-0.5\%GA-2 \%PEI) & 12 & $5.53 \pm 0.06$ & $4.71 \pm 0.21$ & $0.70 \pm 0.04$ \\
\hline 16 & Sty-(SOD-0.01\%BSA-0.5\%GA-2\%PEI) & 9 & $19.53 \pm 0.49$ & $21.17 \pm 1.30$ & $0.61 \pm 0.04$ \\
\hline
\end{tabular}

(a)

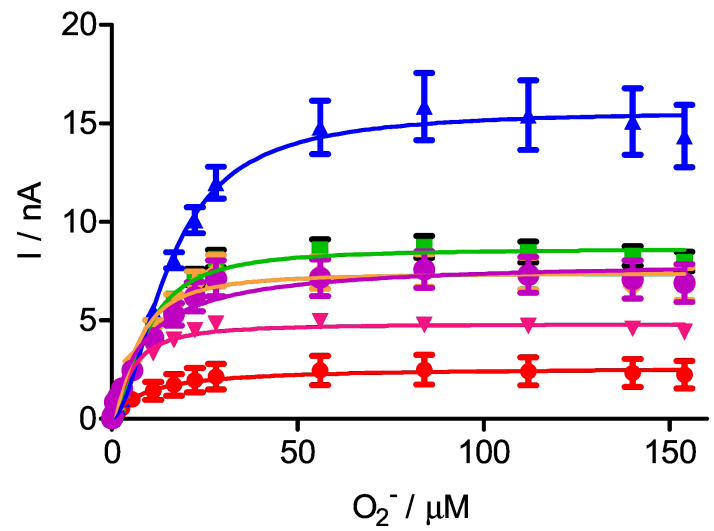

(b)

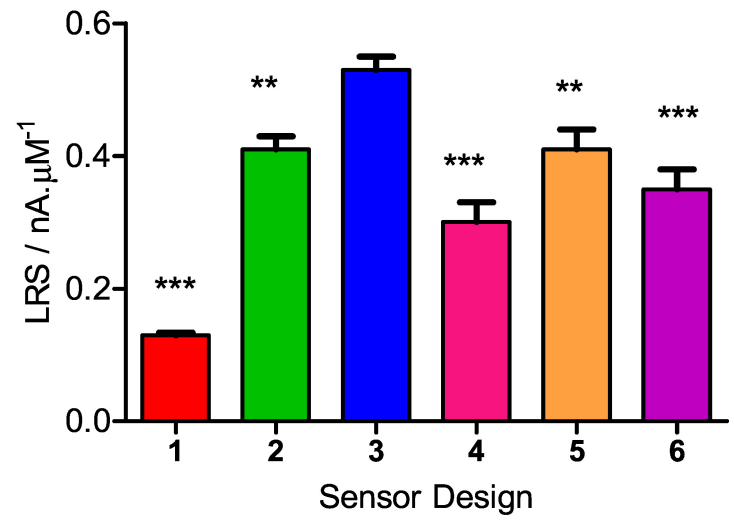

Figure 2. (a) The current-concentration profiles for $\mathrm{O}_{2}^{-}$calibrations (0-154 $\mu \mathrm{M}$ ) for biosensor designs 1 (red), 2 (green), 3 (blue), 4 (pink), 5 (orange) and 6 (purple) calibrated in PBS (pH 7.4) buffer solution containing $0.002 \mathrm{U}$ XOD at $21^{\circ} \mathrm{C}$. Calibrations performed using CPA at $+700 \mathrm{mV}$ vs. SCE. (b) Bar chart comparing sensitivities (Linear Region Slope, $\mathrm{nA} / \mu \mathrm{M}$ ) for biosensor designs 1-6. ${ }^{*} \mathrm{p}<0.05 ;{ }^{* *} \mathrm{p}<0.01$; ${ }^{* *} \mathrm{p}<0.001$ vs. Design 3, unpaired Students t-test.

approach to enzyme loading ${ }^{[4]]}$ on the Pt surface. Also, it has recently been reported that styrene and methyl methacrylate facilitate increased active enzyme loading in biosensors designed for neurochemical monitoring. ${ }^{[42]}$

Designs 1-4 demonstrate the successful immobilisation of SOD $(200 \mathrm{U} / \mathrm{mL})$ by entrapment within a styrene layer on a $\mathrm{Pt}$ $1 \mathrm{~mm}$ cylinder surface. Table 1 highlights the differences in the kinetic parameters for each of the four designs tested with Figure 2(a) showing the Michaelis-Menten plots generated on addition of xanthine $(0-550 \mu \mathrm{M})$ for each of the designs. Design 3 (see Figure 2(b)) displayed a significant improvement in sensitivity $(0.53 \pm 0.02 \mathrm{nA} / \mu \mathrm{M}, \mathrm{n}=8)$ when compared to design $1(0.13 \pm 0.004 \mathrm{nA} / \mu \mathrm{M}(\mathrm{n}=4), \mathrm{P}<0.0001)$, design $2(0.41 \pm$ $0.02 \mathrm{nA} / \mu \mathrm{M}(\mathrm{n}=4), \mathrm{P}=0.0037)$ and design $4(0.30 \pm 0.03 \mathrm{nA} /$ $\mu \mathrm{M}(\mathrm{n}=4), \mathrm{P}<0.0001)$.

In designs 5 and 6 we investigated the effect of changing the concentration of the enzyme solution. The unit of activity was decreased to $100 \mathrm{U} / \mathrm{mL}$ (design 5) and increased to $400 \mathrm{U} /$ $\mathrm{mL}$ (design 6). The ideal enzyme unit of activity was determined to be $200 \mathrm{U} / \mathrm{mL}$ (design 3, see Figure 2(b)) as it produced a high $\mathrm{V}_{\max }$ current of $15.65 \pm 0.24 \mathrm{nA}$, a $\mathrm{K}_{\mathrm{m}}$ concentration of $15.47 \pm 0.54 \mu \mathrm{M}$ and a significant increase in sensitivity when compared to design $5(0.41 \pm 0.03 n A / \mu M(n=12), P=0.0082)$ and design $6(0.35 \pm 0.03 n A / \mu M(n=12), P=0.0003)$. All further design modifications thus utilised 5 layers of $200 \mathrm{U}$ SOD.

\section{Optimisation of Biosensor Design}

The addition of a cross-linking agent such as glutaraldehyde has been utilised regularly in the construction of biosensors to improve enzyme stability. ${ }^{[43,44]}$ Glutaraldehyde usually cross-links with the lysine residues on the enzyme which are typically located on the protein surface rather than the catalytic site, 
(a)

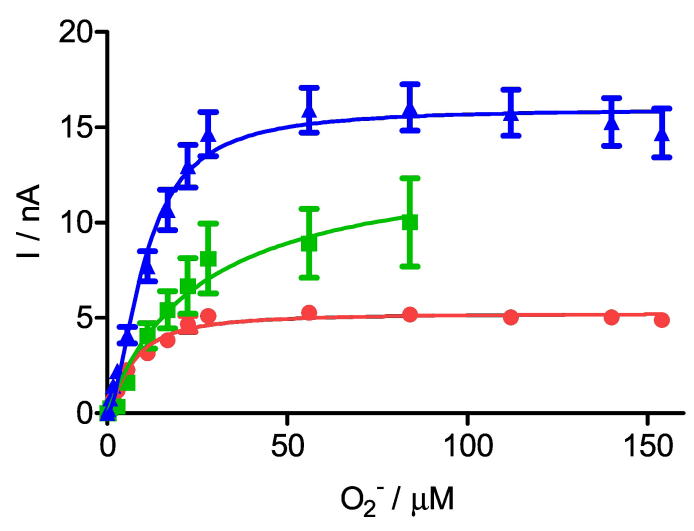

(b)

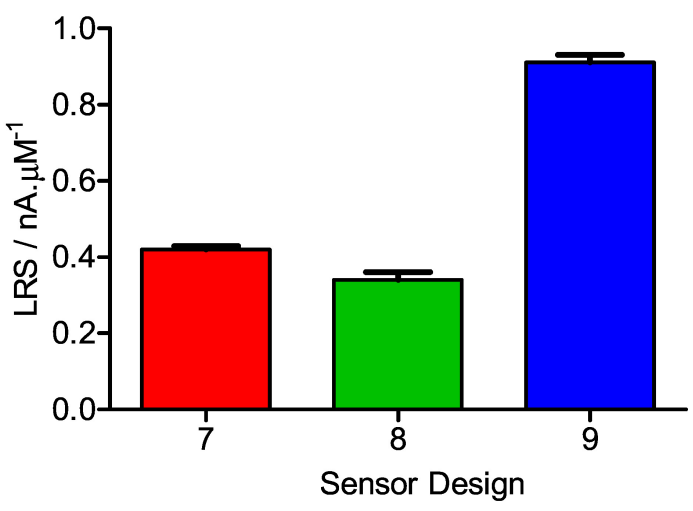

Figure 3. (a) The current-concentration profiles for $\mathrm{O}_{2}^{-}$calibrations (0-154 $\mu \mathrm{M}$ ) for biosensor designs 7 (red), 8 (green) and 9 (blue) calibrated in PBS (pH 7.4 ) buffer solution containing $0.002 \mathrm{U}$ XOD at $21^{\circ} \mathrm{C}$. Calibrations performed using CPA at $+700 \mathrm{mV}$ vs. SCE. (b) Bar chart displaying a comparison of the sensitivities for biosensor designs 7-9.

therefore preserving the protein conformation. Design 7 incorporates glutaraldehyde $(0.5 \%)$ and resulted in a decrease in the $\mathrm{K}_{\mathrm{m}}$ concentration, $\mathrm{V}_{\max }$ and sensitivity when compared to design 3 (see Table 1). The addition of BSA into a biosensor for L-Glutamic acid has previously been reported to protect the enzyme from inactivation during the polymerisation of the enzyme within a PPD film. ${ }^{[45]}$ The inclusion of lysine rich BSA, $1 \%$ into design 8 (see Figure $3(\mathrm{a})$ ) increased the $\mathrm{K}_{\mathrm{m}}$ concentration to $15.02 \pm 1.46 \mu \mathrm{M},(\mathrm{n}=6)$ and the $\mathrm{V}_{\max }$ current to 10.33 $\pm 0.50 \mathrm{nA},(\mathrm{n}=6)$, however a significant decrease $(P=0.001)$ in sensitivity was observed $(0.34 \pm 0.02 \mathrm{nA} / \mu \mathrm{M}, \mathrm{n}=6)$ when compared to design 7. In this instance, the glutaraldehyde crosslinks the BSA in addition to the enzyme thus limiting the direct enzyme cross-linking, resulting in higher enzyme activity and stability.

The polybasic positively charged aliphatic amine polyethylenimine (PEI) has also been incorporated into biosensor designs for both immobilisation ${ }^{[46,47]}$ and stabilisation. ${ }^{[48,49]}$ The introduction of PEI has proven beneficial in the development of biosensors for its ability to increase the sensitivity ${ }^{[46]}$ and reduce the Michaelis constant $\mathrm{K}_{\mathrm{m}}{ }^{[50]}$ These beneficial traits are attributed to the formation of polyanionic/polycationic complexes between the polycation PEI and the polyanionic enzyme which reduces the enzyme deactivation. ${ }^{[51]}$ This can also decrease the electrostatic repulsion between the enzyme substrate and biosensor components, ${ }^{[46]}$ thus leading to the formation of a stable configuration resulting in improved longterm stability of the biosensor. The inclusion of PEI (2\%) in design 9 resulted in a significant increase $(P<0.0001)$ in sensitivity to $0.91 \pm 0.02 \mathrm{nA} / \mu \mathrm{M}(\mathrm{n}=17)$ when compared to design $3(0.52 \pm 0.02 \mathrm{nA} / \mu \mathrm{M}, \mathrm{n}=8)$. This design also yielded a high $\mathrm{V}_{\max }$ current of $15.98 \pm 0.15 \mathrm{nA}$ and a low $\mathrm{K}_{\mathrm{m}}$ concentration of $10.33 \pm 0.27 \mu \mathrm{M}$. Thus, all modified electrodes presented hereafter incorporate PEI into the design as its inclusion has resulted in a substantial increase in sensitivity when compared to designs 1-8.

\section{Concentration Studies}

The previous results observed for designs 1-9 demonstrate that SOD can be successfully immobilised on a Pt surface using the dip adsorption method. However, $\mathrm{O}_{2}^{-}$has a low concentration in-vivo and consequently it was essential to investigate the concentration of the crosslinker and stablisiers in an attempt to improve the kinetic parameters and sensitivity further. The introduction of $\mathrm{PEI}$ resulted in a marked enhancement in the kinetic parameters and sensitivity, thus in designs 10 and 11 we investigated the impact of changing the PEI concentration to $1 \%$ and $3 \%$ respectively. Design 10 resulted in a decrease $(P=0.1554)$ in sensitivity to $0.85 \pm 0.04$ $\mathrm{nA} / \mu \mathrm{M}$, a significant decrease $(\mathrm{P}<0.0001)$ in $\mathrm{V}_{\max }$ to $10.05 \pm$ $0.10 \mathrm{nA}$, and a significant $(\mathrm{P}<0.0001)$ decrease in the $\mathrm{K}_{\mathrm{m}}$ concentration to $6.09 \pm 0.22 \mu \mathrm{M}$, when compared to design 9 incorporating the $2 \%$ concentration of PEI. Design 11 (3\% PEI) produced poor enzyme kinetics and a high $\mathrm{K}_{\mathrm{m}}$ concentration suggesting restricted access of the substrate to the active sites of the enzyme due to higher diffusional constraints.

Literature reports suggest that the amount of cross-linking agent used affects the degree or extent of cross-linking, with low concentrations of glutaraldehyde unable to form sufficient cross-linkages to effect precipitation of the enzyme. ${ }^{[52]}$ Therefore, maintaining the PEI concentration at $2 \%$, the glutaraldehyde concentration was changed to $0.05 \%$ (design 12) and $1 \%$ (design 13) in an attempt to improve the kinetic parameters. Both designs showed poor enzyme kinetics with high $\mathrm{K}_{\mathrm{m}}$ concentrations of $104.70 \pm 20.34 \mu \mathrm{M}$ and $45.90 \pm 4.50 \mu \mathrm{M}$ respectively. A significant decrease $(P<0.0001$ for both designs) in sensitivity was recorded when compared to design 9. Finally, the addition of BSA into sensor designs incorporating both GA and PEI was investigated. Three concentrations were utilised $1 \%$ (design 14), $0.1 \%$ (design 15) and $0.01 \%$ (design 16). The introduction of BSA resulted in a significant decrease in the sensitivity to $0.28 \pm 0.008 \mathrm{nA} / \mu \mathrm{M},(\mathrm{n}=12, \mathrm{P}<0.0001)$ for 
(a)

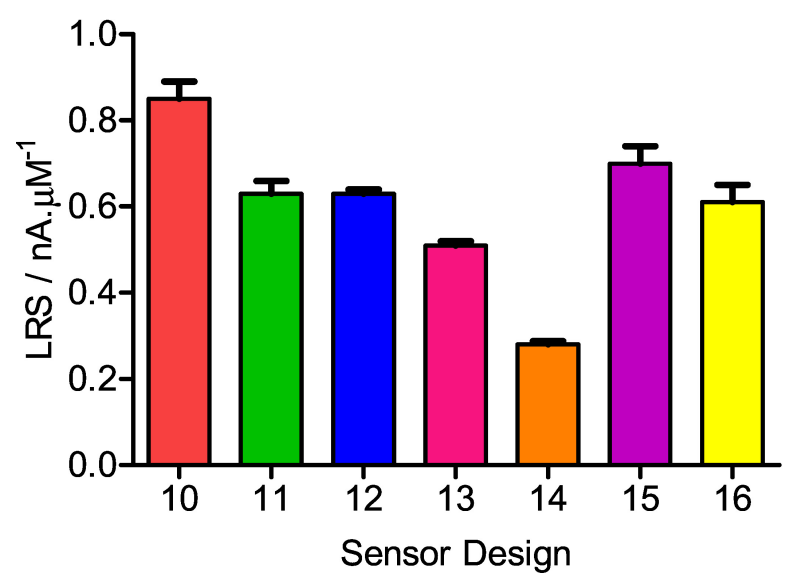

(b)

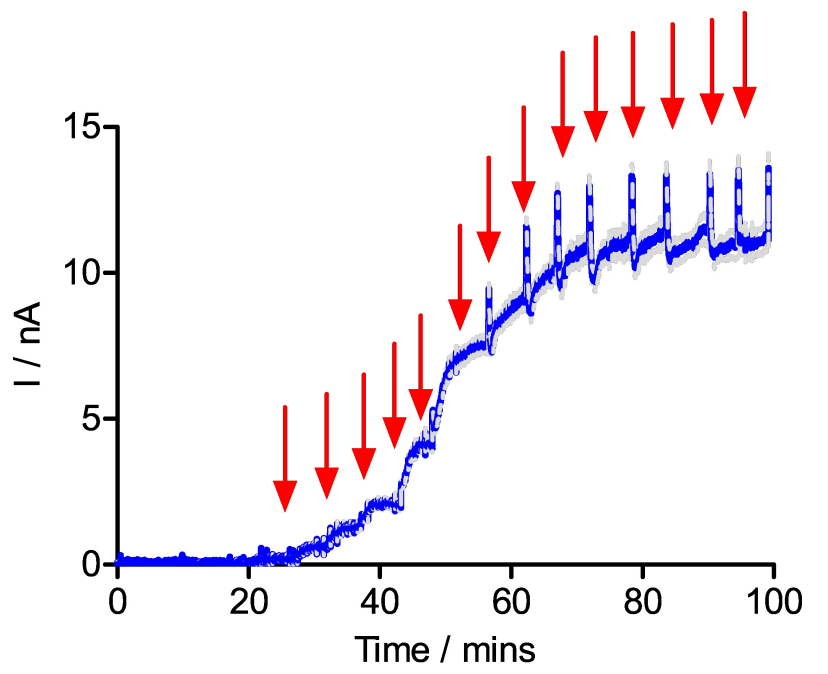

Figure 4. (a) Comparison of the average linear region slope for $\mathrm{O}_{2}^{-}$biosensor designs 10-16. Linear region slope values were obtained from the MichaelisMenten kinetic curve of the $\mathrm{O}_{2}^{-}$calibrations $(0-154 \mu \mathrm{M}$ ) performed using CPA at $+700 \mathrm{mV}$ vs. SCE in PBS (pH 7.4) buffer solution containing $0.002 \mathrm{U}$ XOD. (b) Mean raw data trace for $\mathrm{O}_{2}^{-}$calibration using design $10(\mathrm{n}=4)$. Arrows indicate injections yielding concentrations of $0.28,0.84,1.68,2.8,5.6,11.2,16.8,22.4,28$, $56,84,112,140$ and $154 \mu \mathrm{M} \mathrm{O}_{2}^{-}$.

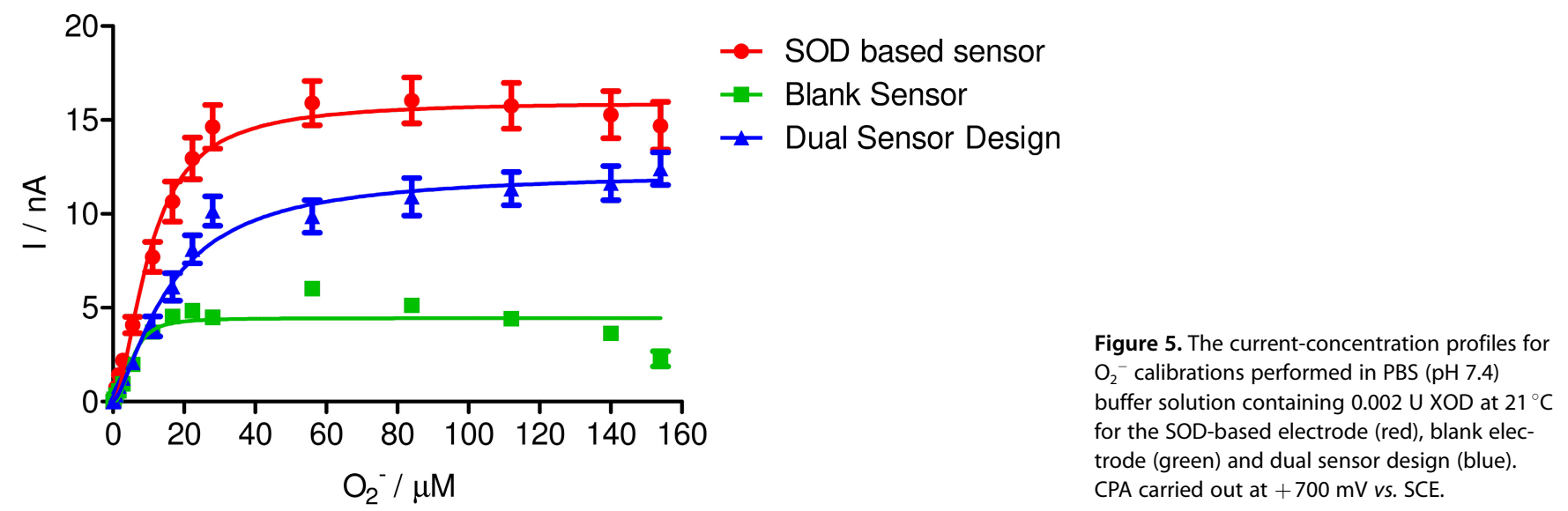

design $14,0.70 \pm 0.04 \mathrm{nA} / \mu \mathrm{M}(\mathrm{n}=12, \mathrm{P}<0.0001)$ for design 15 , and $0.61 \pm 0.04 n A / \mu M(n=9, P<0.0001)$ for design 16 .

\section{Dual Sensor Configuration}

As mentioned previously, $\mathrm{O}_{2}^{-}$undergoes spontaneous dismutation in the electrolyte generating $\mathrm{H}_{2} \mathrm{O}_{2}$. However, this contribution can be eliminated using a dual sensor system. Design 9 demonstrated optimum kinetic parameters and recorded the highest sensitivity compared to other designs. It was therefore utilised in the dual sensor design to detect the spontaneously produced $\mathrm{H}_{2} \mathrm{O}_{2}$ and $\mathrm{O}_{2}^{-}$. The second sensor (blank) incorporates no SOD but was modified with the relevant concentrations and layers of the other components, i.e. styrene, PEI and glutaraldehyde. A subtraction method was utilised in order to find a true representation of the concentration of $\mathrm{O}_{2}{ }^{-}$detected at the $\mathrm{Pt}$ surface and Figure 5 illustrates the dual sensor design in operation. A significant decrease $(P<0.0001)$ in current from $15.98 \pm 0.15 \mathrm{nA}$ (SOD-based electrode) to $2.29 \pm 0.40 \mathrm{nA}$ (blank electrode) was observed at $154 \mu \mathrm{M} \mathrm{O}_{2}^{-}$(Figure 5).This indicates that the spontaneous dismutation of $\mathrm{O}_{2}{ }^{-}$accounts for $\sim 2.30 \mathrm{nA}$ of current generated at the $\mathrm{O}_{2}{ }^{-}$biosensor at $154 \mu \mathrm{M}$ $\mathrm{O}_{2}^{-}$. Similarly, a significant decrease $(\mathrm{P}<0.0001)$ in sensitivity was observed from $0.91 \pm 0.06 \mathrm{nA} / \mu \mathrm{M}$ (SOD-based electrode) to $0.33 \pm 0.005 \mathrm{nA} / \mu \mathrm{M}$ (blank sensor). These results show that the production of $\mathrm{H}_{2} \mathrm{O}_{2}$ from the spontaneous dismutation accounts for only a small proportion of the signal when compared to the signal from the enzymatic dismutation. For future use in-vivo, the two electrodes will be implanted in close proximity to each other and the current from each will be 
recorded simultaneously thus facilitating differential discrimination between the $\mathrm{H}_{2} \mathrm{O}_{2}$ signal due to the spontaneous dismutation of $\mathrm{O}_{2}^{-}$and endogenously produced levels.

\section{Limit of Detection and Time}

The limit of detection (LOD) is an important parameter to consider when designing biosensors to monitor fast transients in brain analytes whose extracellular fluid (ECF) levels are invariably low. We calculated the LOD using three times the error on the lowest calibration concentration $(0.28 \mu \mathrm{M})$ divided by the calibration slope $(0.91 \pm 0.07 \mathrm{nA} / \mu \mathrm{M}$, Design 9). This gives a value of $0.063 \pm 0.004 \mu \mathrm{M}$. In reality one can only use in-vitro calibration curves to guesstimate concentration changes in vivo due to differences in background currents and modifications to the electrode surface resulting from implantation. ${ }^{[53]}$ Variations in signal in-vivo are usually represented as relative changes from background. As such, the LOD for in-vivo sensors is usually determined using the widely applied criterion of three times the standard deviation of the baseline signal $^{[37,54,55]}(0.026 \pm 0.002 \mu \mathrm{M}$ for Design 9). This range would suggest that it may be possible to monitor physiological changes associated with behavioural and/or pharmacological manipulations in-vivo. We also quantified the concentration determination error using the mean LRS to determine the calculated concentration for two standard additions (low and high, within the linear region) of 0.28 and $11.20 \mu \mathrm{M} \mathrm{O}_{2}^{-}$. The values of 0.26 and $10.19 \mu \mathrm{M}$ respectively are very similar to the standard values and represent a discrepancy of $<10 \%$.

Response time, which is defined as the time taken for the response to rise from $10 \%$ to $90 \%$ of the maximum amplitude for a fixed concentration step (i.e. $t_{10-90 \%}$ ), is difficult to separate from the mixing time in in vitro studies. Typical data for the $\mathrm{O}_{2}{ }^{-}$ biosensor is shown in Figure 6 and it is clear that the response

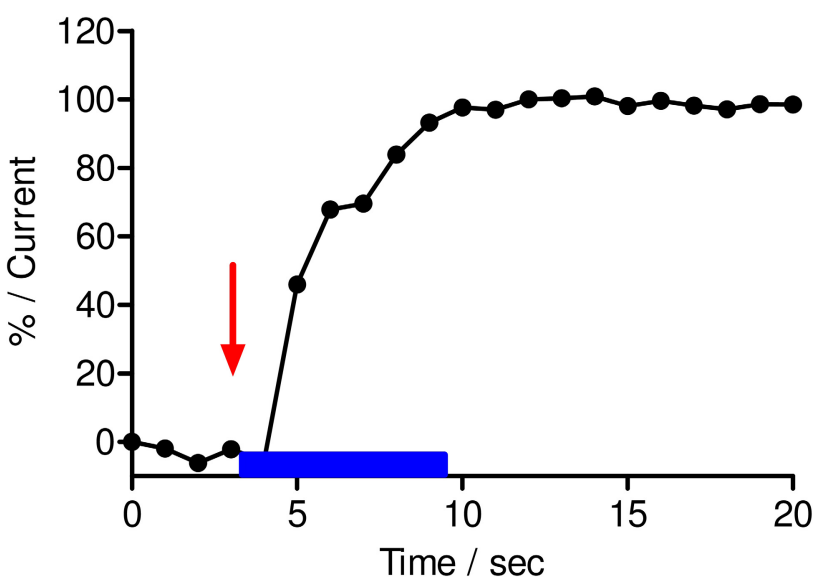

Figure 6. A typical example of a response time for a xanthine injection of 40 $\mu \mathrm{M}$ in PBS ( $\mathrm{pH}$ 7.4) buffer solution at room temperature for the $\mathrm{O}_{2}{ }^{-}$biosensor. CPA carried out at $+700 \mathrm{mV}$ vs. SCE. Arrow indicates the point of injection and the blue rectangle symbolises the stirring time. time is less than the mixing time and of the order of 1-2 seconds. This is similar to the response times reported for other Pt-based biosensors, ${ }^{[56,57]}$ and is ca. 5 times faster than values reported for carbon-based biosensors. ${ }^{[55]}$ Generally, in cases where the $t_{10-90 \%}$ values are less than the mixing time in-vitro, we have found response times in-vivo in the millisecond range. ${ }^{[58-60]}$

\section{Interference Studies}

The brain is anatomically complicated and contains a wide range of electroactive surfactants, electrode poisons, electrocatalysts and a tissue matrix that restricts mass transport to the electrode ${ }^{[31]}$ as well as a large number of possible interfering species present at relatively high concentrations including $A A$, $\mathrm{UA}$, and the catecholamines. The $\mathrm{O}_{2}^{-}$radical has a very low endogenous concentration and therefore it is critical for the biosensor design to eliminate interferent signals while maintaining sufficient sensitivity for the target analyte. The optimised $\mathrm{O}_{2}^{-}$biosensor (design 9) includes the polymer PPD in its construction for interference rejection. This polymer has previously been utilised in the development of biosensors for the detection of glucose, ${ }^{[59]} \mathrm{H}_{2} \mathrm{O}_{2}{ }^{[43]}$ and D-serine, ${ }^{[61]}$ and demonstrates beneficial traits such as being highly permeable to the enzyme generated $\mathrm{H}_{2} \mathrm{O}_{2}{ }^{[34]}$ while effectively rejecting interferent species. ${ }^{[36]}$ The selectivity of design 9 to a range of potential electroactive interferents present in the brain ECF was examined.

AA is considered the main electroactive interferent molecule present in the brain $^{[62]}$ and with an estimated basal concentration of $400 \mu \mathrm{M}^{[63]}$ could readily mask the signal from the nanomolar levels of $\mathrm{O}_{2}^{-}$. Figure 7 shows the AA sensitivity

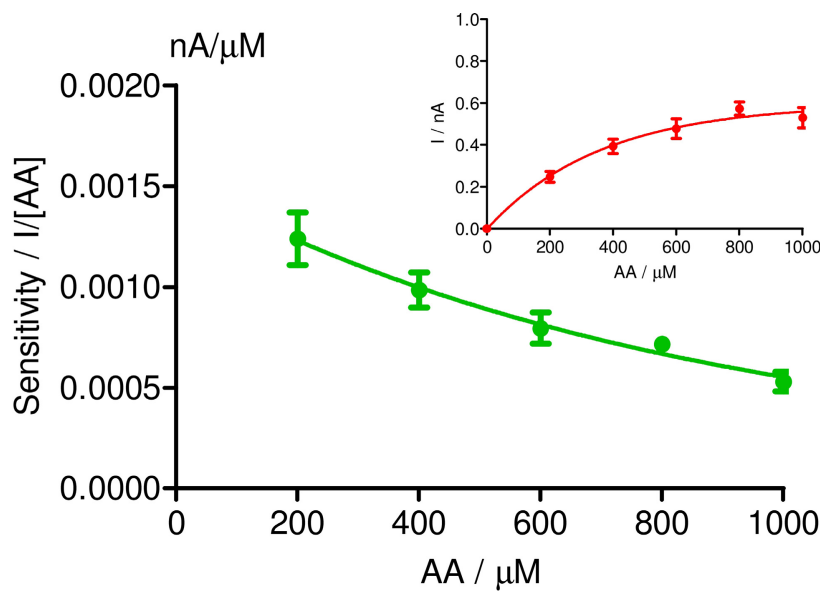

Figure 7. The sensitivity for the $\mathrm{O}_{2}{ }^{-}$biosensor as a function of AA concentration showing significant interference rejection and saturation characteristics at physiological levels. Inset: The mean current-concentration for AA calibrations (0-1000 $\mu \mathrm{M})$ performed in $\mathrm{N}_{2}$ saturated PBS ( $\mathrm{pH}$ 7.4) at $+700 \mathrm{mV}$ (vs. SCE) and $21^{\circ} \mathrm{C}$ using the $\mathrm{O}_{2}^{-}$biosensor.

recorded at the $\mathrm{O}_{2}^{-}$biosensor as a function of varying $A A$ concentration, and the mean current-concentration profile for 
AA calibrations which shows saturation of the PPD layer resulting in a self-blocking phenomenon which has previously been reported. ${ }^{[36,35]}$

Other potential interferents tested (Table 2) included the monoamine neurotransmitters dopamine and 5-hydroxytrypto-

\begin{tabular}{|c|c|c|c|c|}
\hline Interferent & $\mathrm{n}$ & $\begin{array}{l}\text { Concentration, } \\
\mu \mathrm{M}\end{array}$ & $\begin{array}{l}\text { Current Re- } \\
\text { sponse, nA }\end{array}$ & $\begin{array}{l}\text { Signal as \% of current } \\
\text { at } 0.84 \mu \mathrm{M} \mathrm{O}_{2}^{-}\end{array}$ \\
\hline L-Cysteine & 3 & 50 & $\begin{array}{l}0.089 \pm \\
0.056\end{array}$ & $11.4 \%$ \\
\hline L-Tyrosine & 3 & 100 & $\begin{array}{l}-0.050 \pm \\
0.002\end{array}$ & $0 \%$ \\
\hline UA & 3 & 50 & $\begin{array}{l}-0.074 \pm \\
0.008\end{array}$ & $0 \%$ \\
\hline Glutathione & 3 & 50 & $\begin{array}{l}-0.040 \pm \\
0.004\end{array}$ & $0 \%$ \\
\hline DHAA & 3 & 100 & $\begin{array}{l}-0.006 \pm \\
0.001\end{array}$ & $0 \%$ \\
\hline 5-HIAA & 3 & 50 & $\begin{array}{l}-0.046 \pm \\
0.016\end{array}$ & $0 \%$ \\
\hline $\begin{array}{l}\text { L-Trypto- } \\
\text { phan }\end{array}$ & 3 & 100 & $\begin{array}{l}-0.008 \pm \\
0.005\end{array}$ & $0 \%$ \\
\hline HVA & 3 & 10 & $\begin{array}{l}-0.012 \pm \\
0.001\end{array}$ & $0 \%$ \\
\hline Dopamine & 3 & 0.05 & $\begin{array}{l}-0.010 \pm \\
0.000\end{array}$ & $0 \%$ \\
\hline $5-\mathrm{HT}$ & 3 & 0.01 & $\begin{array}{l}0.003 \pm \\
0.005\end{array}$ & $0.38 \%$ \\
\hline DOPAC & 3 & 20 & $\begin{array}{l}0.002 \pm \\
0.002\end{array}$ & $0.26 \%$ \\
\hline
\end{tabular}

maine (5-HT), their metabolites 3,4-dihydroxyphenylacetic acid (DOPAC), homovanillic acid (HV) and 5-hydroxyindoleacetic acid (5-HIAA), dehydroascorbic acid (DHAA), the amino acids Ltyrosine, L-cysteine, L-tryptophan, the purine metabolite UA and the anti-oxidant glutathione.

Small negative currents (attributable to baseline drift) were obtained for most species suggesting no oxidation of the specific interferent. The administration of L-cysteine, 5-HT and DOPAC resulted in small negligible oxidation currents. Also, such signals would be further reduced through co-implantation with the blank sensor and differential signal analysis.

\section{Conclusion}

The detailed in-vitro development of a sensitive $\mathrm{O}_{2}^{-}$biosensor is presented. The use of styrene as the immobilisation matrix facilitated the entrapment of SOD using the dip-coating approach to enzyme loading. The inclusion of the cross-linker glutaraldehyde and the stabiliser polyethylenimine produced a biosensor with excellent sensitivity to $\mathrm{O}_{2}{ }^{-}$and optimum kinetic parameters.

The electroactive interferents $\mathrm{UA}$ and the $\mathrm{H}_{2} \mathrm{O}_{2}$, produced from the spontaneous dismutation of $\mathrm{O}_{2}{ }^{-}$, contribute to the electrochemical signal unless eliminated successfully. The electropolymerisation of $o-P D$ onto the Pt surface provided a successful method to negate the UA contribution without impacting negatively on the $\mathrm{O}_{2}^{-}$sensitivity. A dual sensor design involving the SOD-based electrode (Sty-(SOD-GA-PEI) $)_{5}$ ) and a blank sensor (Sty-(GA-PEI) $)_{5}$ ) was employed to deal with the spontaneous dismutation interference. We also demonstrated the successful rejection of a range of other key endogenous interferent species such as AA, dopamine and metabolites. The resultant fast responding, highly selective and sensitive biosensor has the potential for use in neurochemical monitoring of $\mathrm{O}_{2}^{-}$in-vivo.

\section{Supporting Information Summary}

The experimental section (materials and methods, working electrode preparation, instrumentation and data analysis, and sensor calibration) can be found in the Supporting Information.

\section{Acknowledgements}

We gratefully acknowledge financial support from the Irish Research Council (Project No: RS/2012/152) and Maynooth University John and Pat Hume Scholarships. We thank Caroline H. Reid (Maynooth University) for helpful discussions and Dr. Gama T. Gnahore (Maynooth University) for help in generating the biosensor schematics.

\section{Conflict of Interest}

The authors declare no conflict of interest.

Keywords: Amperometry $\cdot$ biosensor $\cdot$ superoxide $\cdot$ real-time

[1] Y. Tian, L. Mao, T. Ohsaka, Current Analytical Chemistry 2006, 2, 51-58.

[2] K. Krumova, G. Cosa, in Singlet Oxygen: Applications in Biosciences and Nanosciences, Volume 1, Vol. 1, The Royal Society of Chemistry, 2016, pp. 1-21.

[3] C. M. Maier, P. H. Chan, The Neuroscientist 2002, 8, 323-334.

[4] Z. Wang, D. Liu, H. Gu, A. Zhu, Y. Tian, G. Shi, Biosensors and Bioelectronics 2013, 43, 101-107.

[5] Z. Deng, Q. Rui, X. Yin, H. Liu, Y. Tian, Analytical Chemistry 2008, 80, 5839-5846.

[6] C. J. McNeil, P. Manning, Reviews in Molecular Biotechnology 2002, 82, 443-455.

[7] Y. Zhou, J. Ding, T. Liang, E. S. Abdel-Halim, L. Jiang, J.-J. Zhu, ACS applied materials \& interfaces 2016, 8, 6423-6430.

[8] Y. Liu, X. Liu, Y. Liu, G. Liu, L. Ding, X. Lu, Biosensors and Bioelectronics 2017, 90, 39-45.

[9] Z. Wang, L.M. Zhang, Y. Tian, Chinese Journal of Analytical Chemistry 2014, 42, 1-9.

[10] M. Ganesana, J. S. Erlichman, S. Andreescu, Free Radical Biology and Medicine 2012, 53, 2240-2249.

[11] J. R. Harbour, M. L. Hair, The Journal of Physical Chemistry 1978, 82, 1397-1399.

[12] N. Warwar, A. Mor, R. Fluhr, R. P. Pandian, P. Kuppusamy, A. Blank, Biophysical Journal 2011, 101, 1529-1538.

[13] K. Abbas, M. Hardy, F. Poulhès, H. Karoui, P. Tordo, O. Ouari, F. Peyrot, Free Radical Biology and Medicine 2014, 71, 281-290.

[14] Y. Ohara, T. E. Peterson, D. G. Harrison, Journal of Clinical Investigation 1993, 91, 2546-2551.

[15] K. Prasad, J. Kalra, B. Bharadwaj, British Journal of Experimental Pathology 1989, 70, 463-468.

[16] S. Yamaguchi, N. Kishikawa, K. Ohyama, Y. Ohba, M. Kohno, T. Masuda, A. Takadate, K. Nakashima, N. Kuroda, Analytica Chimica Acta 2010, 665, 74-78. 
[17] D. Wang, L. Zhao, L.H. Guo, H. Zhang, Analytical Chemistry 2014, 86, 10535-10539.

[18] Š. Mesároš, Ž. Vaňková, S. Grunfeld, A. Mesárošová, T. Malinski, Analytica Chimica Acta 1998, 358, 27-33.

[19] L. Campanella, G. Favero, L. Persi, M. Tomassetti, Journal of Pharmaceutical and Biomedical Analysis 2000, 23, 69-76.

[20] S. Kintzios, I. Marinopoulou, G. Moschopoulou, O. Mangana, K. Nomikou, K. Endo, I. Papanastasiou, A. Simonian, Biosensors and Bioelectronics 2006, 21, 1365-1373.

[21] K. Endo, T. Miyasaka, S. Mochizuki, S. Aoyagi, N. Himi, H. Asahara, K Tsujioka, K. Sakai, Sensors and Actuators B: Chemical 2002, 83, 30-34.

[22] Y. Tian, L. Mao, T. Okajima, T. Ohsaka, Biosensors and Bioelectronics 2005, 21, 557-564.

[23] L. Wu, X. Zhang, J. Chen, Journal of Electroanalytical Chemistry 2014, 726, $112-118$.

[24] X. Wang, M. Han, J. Bao, W. Tu, Z. Dai, Analytica Chimica Acta 2012, 717, 61-66.

[25] M. Braik, M. M. Barsan, C. Dridi, M. Ben Ali, C. M. A. Brett, Sensors and Actuators B: Chemical 2016, 236, 574-582.

[26] X. Zhu, X. Niu, H. Zhao, J. Tang, M. Lan, Biosensors and Bioelectronics 2015, 67, 79-85.

[27] C. Mateo, J. M. Palomo, G. Fernandez-Lorente, J. M. Guisan, R. Fernandez-Lafuente, Enzyme and Microbial Technology 2007, 40, 1451-1463.

[28] A. Sassolas, L. J. Blum, B. D. Leca-Bouvier, Biotechnology Advances 2012 30, 489-511.

[29] D. R. Thévenot, K. Toth, R. A. Durst, G. S. Wilson, Biosensors and Bioelectronics 2001, 16, 121-131.

[30] R. D. O'Neill, J. P. Lowry, M. Mas, Critical Reviews in Neurobiology 1998, $12,69-128$.

[31] J. Lowry, R. O'Neill, Encyclopedia of Sensors 2005, 501-524.

[32] P. Kuppusamy, J. L. Zweier, Journal of Biological Chemistry 1989, 264, 9880-9884.

[33] R. Aitken, D. Buckingham, D. Harkiss, Journal of Reproduction and Fertility 1993, 97, 441-450.

[34] N. Hamdi, J. Wang, H. G. Monbouquette, Journal of Electroanalytical Chemistry 2005, 581, 258-264.

[35] J. P. Lowry, R. D. O'Neill, Electroanalysis 1994, 6, 369-379.

[36] J. D. Craig, R. D. O'Neill, Analyst 2003, 128, 905-911.

[37] R. D. O'Neill, G. Rocchitta, C. P. McMahon, P. A. Serra, J. P. Lowry, TrAC Trends in Analytical Chemistry 2008, 27, 78-88.

[38] S. Miwa, F. L. Muller, K. B. Beckman, in Oxidative Stress in Aging: From Model Systems to Human Diseases (Eds.: S. Miwa, K. B. Beckman, F. L. Muller), Humana Press, Totowa, NJ, 2008, pp. 11-35.

[39] R. Rakhit, A. Chakrabartty, Biochimica et Biophysica Acta (BBA) Molecular Basis of Disease 2006, 1762, 1025-1037.

[40] M. Pontie, F. Bedioui, Analusis 1999, 27, 564-569.
[41] K. L. Baker, F. B. Bolger, J. P. Lowry, Analyst 2015, 140, 3738-3745.

[42] K. L. Baker, F. B. Bolger, J. P. Lowry, Sensors and Actuators B: Chemical 2017, 243, 412-420.

[43] K. O'Brien, S. Killoran, R. O'Neill, J. Lowry, Biosensors and Bioelectronics 2007, 22, 2994-3000.

[44] E. Emregül, Analytical and Bioanalytical Chemistry 2005, 383, 947-954.

[45] M. R. Ryan, J. P. Lowry, R. D. O'Neill, Analyst 1997, 122, 1419-1424.

[46] C. P. McMahon, G. Rocchitta, P. A. Serra, S. M. Kirwan, J. P. Lowry, R. D. O'Neill, Analyst 2006, 131, 68-72.

[47] K. Reybier, S. Zairi, N. Jaffrezic-Renault, B. Fahys, Talanta 2002, 56, 10151020 .

[48] M. M. Andersson, R. Hatti-Kaul, Journal of Biotechnology 1999, 72, 21-31.

[49] L. Mazzaferro, J. D. Breccia, M. M. Andersson, B. Hitzmann, R. Hatti-Kaul, International Journal of Biological Macromolecules 2010, 47, 15-20.

[50] C. P. McMahon, G. Rocchitta, S. M. Kirwan, S. J. Killoran, P. A. Serra, J. P. Lowry, R. D. O'Neill, Biosensors and Bioelectronics 2007, 22, 1466-1473.

[51] J. Jezkova, E. I. Iwuoha, M. R. Smyth, K. Vytras, Electroanalysis 1997, 9, 978-984.

[52] G. B. Broun, in Methods in Enzymology, Vol. Volume 44, Academic Press, 1976, pp. 263-280.

[53] P. E. M. Phillips, R. M. Wightman, TrAC Trends in Analytical Chemistry 2003, 22, 509-514.

[54] T. T. Nguyen-Boisse, J. Saulnier, N. Jaffrezic-Renault, F. Lagarde, Sensors and Actuators B: Chemical 2013, 179, 232-239.

[55] N. V. Kulagina, L. Shankar, A. C. Michael, Analytical Chemistry 1999, 71, 5093-5100.

[56] Y. Hu, G. S. Wilson, Journal of Neurochemistry 1997, 68, 1745-1752.

[57] F. Tian, A. V. Gourine, R. T. R. Huckstepp, N. Dale, Analytica Chimica Acta 2009, 645, 86-91.

[58] J. P. Lowry, M. Miele, R. D. O'Neill, M. G. Boutelle, M. Fillenz, Journal of Neuroscience Methods 1998, 79, 65-74.

[59] J. P. Lowry, K. McAteer, S. S. El Atrash, A. Duff, R. D. O'Neill, Analytical Chemistry 1994, 66, 1754-1761.

[60] F. B. Bolger, S. B. McHugh, R. Bennett, J. Li, K. Ishiwari, J. Francois, M. W. Conway, G. Gilmour, D. M. Bannerman, M. Fillenz, M. Tricklebank, J. P. Lowry, Journal of Neuroscience Methods 2011, 195, 135-142.

[61] Z. M. Zain, R. D. O'Neill, J. P. Lowry, K. W. Pierce, M. Tricklebank, A. Dewa, S. A. Ghani, Biosensors and Bioelectronics 2010, 25, 1454-1459.

[62] F. O. Brown, J. P. Lowry, Analyst 2003, 128, 700-705.

[63] M. Miele, M. Fillenz, Journal of Neuroscience Methods 1996, 70, 15-19.

Submitted: April 14, 2017

Revised: May 4, 2017

Accepted: May 8, 2017 